\title{
Patrick MacGill: Traducción al español de una selección de sus poemas y semblanza crítica
}

\author{
José Manuel Pulido \\ Investigador independiente
}

Copyright (c) 2021 by José Manuel Pulido. This text may be archived and redistributed both in electronic form and in hard copy, provided that the author and journal are properly cited and no fee is charged for access.

\begin{abstract}
During the First World War, Patrick MacGill served with the London Irish Rifles, although once in the conflict, he worked as a stretcher-bearer. On the battlefield, he wrote his war novels and his book of poetry, Soldier Songs, where the poems "The Cross", "I Will Go Back" and "The Trench" are included. In this article, the reader will find the first translation into Spanish of these three poems and a critical profile, overviewing MacGill's life from his birth in Glenties to his death in the United States and analysing how his literary production is related to his own experiences and certain decisions taken, which will influence both his successes and failures.
\end{abstract}

Keywords. Patrick MacGill, First World War, Donegal, Canon Dalton, navvy, translation.

Resumen. Patrick MacGill participó en la Primera Guerra Mundial como fusilero del regimiento London Irish Rifles, aunque una vez en el conflicto, trabajó como camillero. En el campo de batalla escribió sus novelas de guerra y su libro de poesías, Soldier Songs, donde se incluyen los poemas "The Cross", "I Will Go Back" y "The Trench", cuyas traducciones por primera vez al español se presentan en este artículo. El lector también podrá encontrar una semblanza crítica, haciendo un recorrido por la obra y vida de MacGill desde su nacimiento en Glenties hasta su muerte en Estados Unidos y analizando cómo toda su producción literaria está relacionada con sus vivencias y con determinadas decisiones tomadas, que influirán tanto en sus éxitos como en sus fracasos.

Palabras clave. Patrick MacGill, Primera Guerra Mundial, Donegal, Canon Dalton, navvy, traducción.

\section{Semblanza Crítica de Patrick MacGill}

Patrick MacGill nace el 24 de diciembre de 1891 en Glenties, Co. Donegal, Irlanda. El primero de once hermanos, se cría en una pequeña granja a unos cuantos kilómetros del centro de la ciudad, en un lugar llamado The Glen. Como otros muchos niños de su generación, asiste durante cortos 
períodos de tiempo a la escuela y abandona ésta y su casa por la hiring fair en Strabane en el vecino condado de Tyrone. Sus padres, como la mayoría de padres en esta zona agreste y necesitada de Donegal, no tuvieron otra elección que enviar a sus hijos fuera para ser "contratados" como empleados de grandes granjas situadas en el Lagan - una región próspera en agricultura que se extiende desde el este de Donegal y comprende Derry, Tyrone y Fermanagh. En líneas generales, estos niños tenían desde once años en adelante, pero la forzosa salida de sus casas significaba menos bocas que alimentar y el dinero que ellos ganaran (alrededor de 5 libras por seis meses de trabajo) ayudaría a comprar comida para el resto de la familia y pagar el alquiler al terrateniente. No todos los chicos y chicas eran contratados. Los granjeros que asistían a la feria que tenía lugar dos veces al año en esta región inspeccionaban minuciosamente el estado de los jóvenes que permanecían de pie en las calles de la ciudad y, si parecían enfermos o débiles, había pocas posibilidades de que fueran contratados.

Patrick MacGill estaría entre los primeros en escribir su experiencia, y más tarde, se referiría a la feria de Strabane como "the slave market" (MacGill, Children of the Dead End 48). Los jóvenes contratados como MacGill normalmente pasaban unos años en las granjas de Lagan, aunque algunos preferían estar con el mismo señor, antes de desviarse a las Lowlands de Escocia, donde se asegurarían un trabajo en las granjas de allí y, particularmente, en los campos de patatas y nabos. Los trabajadores escoceses preferían dedicarse a la industria porque se les pagaba mejor, dejando aquel trabajo para los trabajadores provenientes de Donegal y de otros condados del litoral oeste que lo necesitaban desesperadamente para poder subsistir. Las cuadrillas de inmigrantes recogedores de patatas empezaron a ser conocidos como los "tatie hokers". Después de un tiempo, muchos de ellos se pasaron a la industria y a la construcción, siendo una constante en Escocia en este período y durante décadas sucesivas.

El joven MacGill, tras trabajar en la recolección de patatas y recorrer los caminos de Escocia trabajando aquí y allá, finalmente consigue un trabajo en la línea de tren GlasgowGreenock cuando ya contaba con 18 años. Así, siguió los mismos pasos de los jóvenes de Donegal de décadas antes y después, y su historia habría sido igual a las demás si no hubiera sido por el hecho de que era un joven sensible, con talento, ávido de conocimiento, con habilidad para escribir y ambición por mejorar. Aunque tenía una educación básica, leía con voracidad. Su poeta favorito era Kipling, que era muy popular en aquel tiempo a lo largo y ancho del Imperio Británico. En prosa, lo que particularmente le atraía era el realismo social de Tolstoi, Gogol, Zola y Víctor Hugo porque se identificaba con ellos.

Su poesía, la mayoría basada en su propia experiencia como peón, reflejaba su creciente interés por el pobre y el oprimido y por aquellos peones, que, como él, trabajaban duro en la suciedad para construir "civilización" mientras ellos vivían al margen de la sociedad. En 1910, publica su primera colección de poesía, Gleanings from a Navvy's Scrapbook, que él mismo se publicó y vendió a seis peniques la copia de puerta en puerta en Greenock, donde vivía por aquel entonces. Una de las puertas a las que llamó fue la del novelista y periodista Neil Munro, que escribió sobre MacGill en The Glasgow Evening:

He has done even better than the majority of modern poets who venture upon the publication of their own works under more favourable circumstances than his, for he has induced a good many people to buy his poetry who never indulged in any such extravagance before, and he is likely to have a modest profit left after meeting with his printer [...] MacGill is a native of Ulster, as his tongue betrays. "The fact that everything has been said about everything does not naturally suggest that everything has been sung about everything", he remarks in his Introduction to his booklet. "Some day - when I become famous - I will take immense pleasure in reminding the world, like Mr. Carnegie, that I started on the lowest run of the ladder, or, as is more correct, in looking for the spot where the ladder was placed". (The Glasgow Evening, 13 February, 1911) 
Esta reseña, junto a los artículos que había remitido al Daily Express londinense, desembocó en una oferta de trabajo por parte del diario, como el propio MacGill comenta en una entrevista a dicho diario:

When I was 19 I published a volume of verses, which I called "Gleanings from a Navvy's Scrap Book" and between 8,000 and 9,000 copies were sold. The book was got out very cheaply, and it paid me well. It is realism that pays nowadays. Poems on heathen gods and mythology are not saleable; people want a spice of realism, and I gave it to them.

While I was at work on a new volume, Mr. Pearson, of The Daily Express, who had read one of my books forwarded for review, wrote and offered me a post on his editorial staff. I replied that although I was a writer among navvies, I was only a navvy among writers, but he persisted in my coming to London, and so I became a journalist. [...] I see that a Scottish reviewer, in speaking of my verses, says that I have neither religion, creed nor God. Well, I think we all have a god of some sort. Life is full of ironies, and truth is not a marketable commodity. (Daily Express, 19 February, 1913)

Este acontecimiento supuso un punto de inflexión en su vida, que cambió radicalmente. En el transcurso de unas semanas, el peón se había convertido en periodista de Fleet Street con un libro de poesía en su haber.

Su carrera periodística fue efímera, pero la leyenda del Navvy Poet crece y se adorna cuando el excéntrico e influyente Canon Sir John Dalton (Rev. J. N. Dalton), capellán de la reina Victoria y tutor de los príncipes Eduardo y Jorge, le ofrece alojamiento en el Castillo de Windsor y un trabajo como traductor de manuscritos para mantenerse, a cuya oferta MacGill responde el 18 de enero de 1912:

Dear Canon,

[...] Regarding your offer of a job for which I am very grateful will you tell me?

(1) If I wasn't idle, would you require another to do it?

(2) If so, what pay would you give? You know there are hundreds who would do the work, working 10 hours a day, for 25/a week and less.

If I take the job will I have to stop in Windsor. I would be awful pleased to accept the work, but I'm half suspicious that is merely because I'm idle you've found the job.

The fact is, if I could stop in London, until the book is published and sold, I would be very pleased. Then thank goodness I can work.

Yours sincerely,

Patrick MacGill

Se ha insinuado que MacGill le envió una copia de su primer libro de poemas (y otro libro, pero de otro autor porque el único que había publicado MacGill hasta esa fecha era Gleanings from a Navvy's Scrapbook) a Dalton, y es probable que así fuera, según una carta que envió a Dalton el 24 de noviembre de 1911:

Dear Canon,

I have just sent you the books as desired. You wanted some excuse to send me that 10/. I am liking my job a little better now.

Thanks for your order.

Very sincerely,

Patrick MacGill

Algún crítico, como O’Sullivan (208), ha llegado a comentar que Dalton tenía un interés homoerótico por hombres jóvenes de la clase trabajadora, y MacGill era un hombre guapo, a juzgar 
por la fotografía que aparece en una página de Gleanings. No obstante, el principal interés de Dalton era entablar amistad con gente que no tuviera nada que ver con su estatus social porque no se sentía cómodo dentro de esa élite y para impactar a los miembros más formales de su propia clase social. Su hijo Hugh Dalton habla así de su padre:

My father did not like Liberals. He was a Tory Democrat. No one I have ever known was less of a snob and less like the traditional picture of a courtier. He made friends, on equal terms, with all sorts and conditions of men. He had no use for lords, or rich men, as such [...] Among his friends, with whom he maintained contact and correspondence for many years, were Edward Carpenter, a friend of his undergraduate days at Cambridge, known to British Socialists as the author of England, Arise; and Towards Democracy; Patrick MacGill, the "Navvy Poet" from County Donegal; and Arthur Benson, Eton Master, Public School Reformer, Poet and Master of Magdalene College, Cambridge. (Greacen 6)

Bajo el auspicio de Dalton, el joven trabajador de Donegal era ahora capaz de proseguir con su escritura en un ambiente más agradable que en la cabaña de un peón o en una casa de huéspedes. Otro libro de poesía, Songs of a Navy (1912), con unos versos más logrados y otra vez publicado por él mismo, apareció poco tiempo después. Al año siguiente, MacGill no tuvo ningún problema en encontrar un editor en Londres, Herbert Jenkins, para su tercer libro de poesía, Songs of the Dead End, una colección de sus dos trabajos anteriores a los que se añade una poesía de posterior composición.

Inspirado por sus muchas lecturas, MacGill pasó de la poesía a la prosa, y en 1914 su primera novela, Children of the Dead End, causó sensación hasta el punto de que se vendieron aproximadamente 10.000 copias en tres meses en Gran Bretaña y Estados Unidos, pero no en Donegal, donde no fue muy bien recibida según palabras del propio MacGill:

"In my own place", writes Mr. Patrick MacGill, speaking of his Children of the Dead End, "I am looked upon with suspicion, all because 'I wrote a book, a bad one makin' fun of the priest', as an old countryman remarke to me last summer when I was at home. 'You don't like it, then?' I said. 'Like it! I wouldn't read it for a hundred pounds, money down' was the answer”. (The New York Tribune, 29 july, 1915)

El subtítulo del trabajo fue The Autobiography of a Navvy, y en él, el joven autor de 23 años vierte una descripción colorida e intensa de la vida que Dermod Flynn (su alter ego en la novela) había llevado hasta entonces, la lucha de su familia por la existencia, sus días como chico contratado en Tyrone, las duras condiciones que tuvo que soportar en los campos escoceses y los personajes que conoció en las chozas de los peones en Escocia. Como la organización obrera estaba tomando poder en la tierra, MacGill encuentra una voz nueva y formidable a favor de la clase trabajadora porque él era de esa clase social y había compartido, aunque brevemente, las duras condiciones y el aislamiento a los cuales estaban sometidos. No obstante, MacGill también atacó al sistema, no solamente en Gran Bretaña, sino también en Irlanda, por las pésimas condiciones en las que él y tantos de sus compatriotas vivían y trabajaban en aquel tiempo. Esta crítica está centrada no solamente en los terratenientes, sino también en el cura y su amigo, el comerciante local, a quienes acusaba de explotar a la gente:

[...] It is a paradox to pretend that the thing called Christianity was what the Carpenter of Galilee lived and died to establish. The Church allows a criminal commercial system to continue, and wastes its time trying to save the souls of the victim of that system. Christianity preaches contentment to the wage-slaves, and hob-nobs with the slave drivers; therefore, the Church is a betrayer of people. The Church soothes those who are robbed and 
never condemns the robber, who is usually a pillar of Christianity [.... To me the industrial system is a great fraud, and the Church which does not condemn it is unfaithful and unjust to the working people. (MacGill, Children of the Dead End 57)

Al estallar la Primera Guerra Mundial en 1914, MacGill se alista ese mismo año en The London Irish Rifles. A pesar de pertenecer a este regimiento, se sentía tan irlandés como el que más, aunque era un irlandés atípico porque se sentía bastante cómodo luchando en el ejército británico. Ser un soldado no necesariamente reemplazaba el hecho de ser irlandés y MacGill trata de demostrarlo, pero ambos hechos se solapaban, al menos de cara a la opinión pública porque muchos nacionalistas irlandeses llegaron a pensar que esa supuesta ausencia de "irlandesismo" de MacGill estaba provocada por la vida militar, por el ejército en el que se encontraba y porque lo anti-irlandés vendía, como escribe un contemporáneo de MacGill, Patrick McCarry, en una carta publicada en el periódico Derry Journal en 1979:

Sir- Regarding the long flowery blown up story about the prince of Donegal writers, Patrick MacGill, written in the Derry Journal on Friday, January 18, I am a man who forever regrets paying a half-crown to go in and hear a lecture given by MacGill, when he was given the freedom of Rothesay, Isle of Bute. A dozen of us Donegalmen believed we were supporting a great man from home. We were in for a shock. With the Lord Mayor and all the Council dressed in evening suits, on stage, out came MacGill. He started telling of hard times at home as a boy, criticizing his own father and mother, giving all secrets of their private lives, telling of his father writing him to send a $£ 1$ right away as another baby was born. Anything anti-Irish at that time sold like hot cakes, so he blamed the parish priest for the big family and this was his sure winner. He followed the road to success. I sincerely hope I am hurting no one by my knowing more than most about how the long story in your paper should have read. (Greacen 14)

Los propios nacionalistas llegaron a considerar a aquellos que se unían al ejército como "not Irishmen but English soldiers, more English than the English themselves", pero de lo que no hay duda es de que MacGill quería a Irlanda y que su idea de regresar a su país después de la guerra siempre estuvo en su pensamiento, porque sus raíces estaban allí y él se sentía uno más de ellos.

Desde el frente, escribe artículos para el Daily Mail y otros periódicos británicos. Durante la batalla de Loos (1915), resulta herido y trabaja para el servicio de inteligencia hasta el final de la guerra, probablemente porque el ejército no quería sus posibles denuncias después de Loos.

Es en 1915 cuando MacGill contrae matrimonio con Margaret Gibbons, escritora de novela romántica y bisnieta del cardenal Gibbons de Baltimore. Además, en este mismo año dos libros suyos ven la luz: The Rat-Pit y The Amateur Army. La historia de The Rat-Pit es similar a la de Children of the Dead End, pero desde la perspectiva de Norah Ryan, uno de los personajes que aparecen en aquella novela. En The Rat-Pit, MacGill presenta a Norah como una chica devota e inteligente de Donegal que abandona su casa después de la muerte de su padre esperando encontrar una vida mejor en Escocia. Incapaz de evitar el ciclo de la pobreza, el destino de Norah está sentenciado cuando se queda embarazada de Alec Morrison, el hijo de un granjero en cuyas tierras ella vivía y trabajaba en penosas condiciones. A pesar de sus grandes ideales y puntos de vista sobre la justicia social, Alec la abandona y demasiado orgullosa para aceptar su oferta de ayuda financiera, Norah se encuentra sola con un hijo vagando por las calles de Glasgow y tiene que ejercer la prostitución para intentar salir adelante. La forma en la que MacGill presenta a todos los personajes, y en especial a las mujeres, muestra su capacidad para ahondar en sus pensamientos, inspirado en el material que recogió cuando las vecinas de su madre iban a casa a cotillear, de las mujeres que conoció en la recolección de patatas o de las prostitutas que entrevistó. Su mujer Margaret Gibbons también le fue de gran ayuda, hasta el punto de que Dudley Edwards considera que The Rat-Pit debe mucho de su fuerza como trabajo de literatura feminista a la chica americana 
que ayudó a Macgill a desarrollar la novela (83). MacGill se siente más cómodo y seguro con su material femenino después de que su mujer le ayudara a analizarlo y profundizar en el estudio de toda esa información que tenía porque le aportó el punto de vista femenino, aunque no perteneciente a la misma clase social que las mujeres que aparecen en la novela, porque las condiciones sociales de los suburbios de Glasgow distan mucho de la residencia de su tío-abuelo en Baltimore o de los prósperos negocios de su padre en Nueva Orleans.

El mismo año de publicación de The Rat-Pit, MacGill publica The Amateur Army, donde en fecha de su publicación, MacGill seguía siendo miembro del London Irish Rifles y, debido a su crítica del régimen de entrenamiento en el ejército, sufrió la amenaza de un consejo de guerra, aunque el asunto no fue a mayores y pudo seguir escribiendo.

En 1916, MacGill publica otras dos novelas, relacionadas con la Primera Guerra Mundial: The Red Horizon y The Great Push. En la primera, MacGill muestra el poder del hombre que dependía más de la clase social que de la etnia o religión y que mantenía un fuerte sentimiento del llamado "romanticismo de la guerra" porque cuando MacGill refleja su experiencia en las trincheras, habla sobre "his heart stirred with the romance of his mision" (MacGill, The Red Horizon 301) y del "mystery, the enchantment and the glamour" (MacGill, The Red Horizon 302). Sin embargo, este romanticismo se rompe al plantearse MacGill ciertas situaciones que se dan en la guerra como matar a un hombre con la bayoneta:

"To the war! To the war!" I said under my breath. "Out to France and the fighting!" The thought raised a certain expectancy in my mind. "Did I think three years ago that I should ever be a soldier?" I asked myself. "Now that I am, can I kill a man; run a bayonet through his body; right through, so that the point, blood red and cruelly keen, comes out at the back? I'll not think of it". (The Red Horizon 14)

El pasaje censurado de "Out There", que aparece reimpreso en los capítulos iniciales de The Red Horizon, parece indicar, según Edwards (75), una línea de unión entre MacGill y los poetas disidentes de la guerra, porque MacGill no apoyaba la guerra, sino que la veía como la sinrazón del ser humano, donde las clases pobres morían en contraposición a las clases altas que permanecían tranquilamente en sus casas ajenas al dolor y sufrimiento del conflicto. Al nuevo nacionalismo irlandés nunca le gustó el debate sobre el apoyo de sus partidarios al esfuerzo británico en la guerra y habían aprendido de sus errores: querían irlandeses que estuvieran comprometidos con la causa y sin relación con Gran Bretaña. Por todo esto, MacGill poco tenía ya que hacer con su método autobiográfico.

En The Great Push, al igual que en el resto de sus novelas de guerra, MacGill sigue mostrando los conceptos de camaradería, coraje y sacrificio, que fueron en un principio destrozados por la realidad de la guerra, al igual que esta destrozó la seguridad de MacGill en sí mismo, que había demostrado durante los primeros meses en el frente, para convertirle en un camillero lleno de dudas y con el dilema moral de a quién atender primero:

And up the street, down in the cellars, at the base of the Twin Towers, they were dying. How futile it was to trouble about one when thousands needed help. Where should I begin? Who should I help first? Any help I might be able to give seemed so useless. I had been at work all the morning dressing the wounded, but there were so many. I was a mere child emptying the sea with a tablespoon. (MacGill, The Great Push 60)

Este mismo año, McGill publica Soldier Songs, ${ }^{1}$ su única colección de poesía sobre la Primera Guerra Mundial. En ellas podemos encontrar la idea de las canciones como un canal informal de protesta contra las circunstancias y contra la opresiva, incompetente e impopular autoridad política y militar. 
MacGill, que es el narrador de sus Soldier Songs, representa el mismo papel que desempeñaría un narrador de cuentos. Él aprende de una fuente conveniente, la de sus compañeros y la de su propia experiencia, y a partir de ahí las interpreta, quizás cambiando y enriqueciendo su contenido. La interpretación en sí es bastante informal y suele estar acompañada de la consumición de algún tipo de bebida alcohólica, en especial de licor o vino, que contribuyen a reafirmar amistades, intercambiar anécdotas y cantar a coro, que es uno de los pilares sobre los que se asientan las Soldier Songs. Estas difieren de otros muchos textos o poemas escritos sobre la Primera Guerra Mundial en los que MacGill nos da una visión de la guerra diferente en el sentido de que la acción es importante, pero los sentimientos de las personas que toman parte en el conflicto lo son más. Quizás sea esto lo que nos lleve a considerar las Soldier Songs no como una poesía de guerra propiamente dicha, sino como "una poesía de sentimientos humanos en tiempos de guerra".

En 1917, MacGill publica The Brown Brethren, una novela escrita como propaganda y cuyo propósito, según Starr (94), no era solamente el de entretener sino un medio para persuadir al público británico y americano de la eficacia de la causa aliada y para animar a que más hombres cogieran las armas. El periódico australiano The Catholic Press en su edición del 30 de mayo de 1918 es muy crítico con la calidad de la obra de MacGill: "If some friend of Patrick MacGill could have persuaded him not to publish 'The Brown Brethren', that Irish soldier's literary reputation would be higher than it is now. The book is composed of the ribald conversations and coarse pranks of a party of British trenchmen".

Por su parte, The Sunday Times de Sydney hace una crítica más constructiva de esta novela, mostrando las luces y las sombras de la narrativa de MacGill:

Mr. Patrick MacGill's verse is now better than his prose, and as to his prose of the war it looks at times as if his vein is being worked thin. There is no lack of good stuff in this new book about soldiers and the actual strain of war, but there is not the consistent grip notable in some earlier books by the same writer. There are even signs here and there that Mr. MacGill is in danger of succumbing to the literary conventions [...] It is a vividly interesting book not quite the peer of its precursors, but very well worth a place on the shelf. (The Sunday Times, 20 January 1918)

En 1919, MacGill publica Glenmornan, la cual no fue muy bien acogida en Irlanda por su anticlericalismo, ya que el personaje de Fr. Devaney, a quien MacGill describe como "a little potbellied man with white shiny teeth, who smoked ninepeeny cigars and always travelled first-class in a railway train" (Children of the Dead End 11), está basado en una visión negativa del canónigo Macfadden de Iniskeel. Este era una figura importante de la Land League y autor de panfletos sobre el tema de la posesión de tierras. Canon Macfadden estuvo en prisión por estar a favor de la ocultación de las rentas en 1888. Durante un segundo intento para arrestarle el 3 de febrero de 1889, se desató un tumulto que terminó con la muerte del Inspector del distrito. Se le acusó junto a otras doce personas más, pero quedó en libertad; se retiró a Iniskeel y se abstuvo de cualquier agitación. Conocido como An Sagart Mór por su despótico trato hacia los parroquianos, es duramente tratado en la narrativa de MacGill también en esta novela (ya había criticado a la Iglesia en The Rat-Pit y en Children of the Dead End) porque no había ningún cambio de actitud para con los feligreses. El propio MacGill en su prólogo de The Rat-Pit habla de la opinión que tiene la Iglesia sobre sus novelas: "[...] The references to a tyrannical village priest gave great offence to a number of clergy, but on the other hand several wrote to me speaking very highly of the book, and I have been told that a Roman Catholic Bishop sat up all night to read it" (The Rat-Pit XVI).

En 1919, MacGill, bajo el pseudónimo de John O'Gorman, publica The Dough-boys, pero la guerra ya había terminado y el propósito principal de la novela, la propaganda, se desvaneció. MacGill habla así de esta novela en una carta escrita a Canon Dalton el 27 de febrero de 1919 y le anticipa la publicación de sus dos próximas novelas: Maureen (1920) y Fear (1921): 
My dear John,

Please to find herein my latest book, a story dealing with the visit which I paid to the ground over which the Australians fought in the offensive of last Summer and Autumn. It is a bit incoherent and lacking in the finish, but such a thing can be forgiven in the days of stress and war. It was written as propaganda, but served no purpose in that direction for the war stopped just as it was completed and it was a case of either throwing it in the wate paper basket or using it in any way I though fit for my own purpose. [...] I am writing as usual and have two books on the stocks now, one dealing with Ireland and another with war. This second will have a certain pacific tendency and will deal with the stark realism of war, not with that Jingo-spouting, flat-wagging, doing-your-bit pattern, but with the more real human heart, crucifiying aspects of the contest. I shall do my best to make this book of my greatest $[\ldots]$

With fondest love, my dear John,

Patrick

En Maureen (1920), la epónima heroína es hija ilegítima y trabaja para la señora Thornton en el condado de Tyrone, que la hace vivir cuidando a niños huérfanos que mueren de hambre y carecen de higiene. Coincide la publicación de esta novela con el decreto del Gobierno irlandés que aboga por separar los parlamentos del Norte y del Sur de la isla y los editores promocionaron esta novela como a "Sinn Fein novel": MacGill nunca mostró interés por el nacionalismo irlandés, pero sí alguno de sus personajes de esta novela, como MacGill, comenta en una carta a John Dalton el 30 de abril de 1919:

My dear John,

[...] Of course both of us are working, Margaret at her stories and myself at my new Donegal book which will be out in the late Autumn. I have all manner of queer characters in the pages, shoemakers, makers of potheen, farmers, servant girls, Sinn Feiners, policeman and priests. This priest, the one who comes in for special attention, is a very good fellow and I'm sure that Irish people will like him. I describe as far as I am able the outlook of the country under Sinn Fein and to this end tell how the old woman, Peggy Ribbig, fears the coming of an Irish Republic, ¡because if it comes she says "The King iv England will never send me the Old Age pension!" But her husband, the ancient Condy Heelagh thinks differently. He is the owner of an antique fowling piece which might have been used by The Man in the Garden at the beginning of time. "Maybe I'll get some one to buy it when the war comes", he says hopefully. Of course the book is not near an end yet, but by hard work I hope to have it completed by the end of June. [...]

With the best love

As always,

Patrick

En 1921, aparece su último libro de poesías, Songs of Donegal. En una carta escrita a Herbert Jenkins, su editor, y fechada el 5 de noviembre de 1920, MacGill le da las gracias por publicar el libro el Armistice Day, y en una larga postdata habla sobre enviar ejemplares a críticos en el más amplio sentido de la palabra:

My Dear Jenkins: -

Glad you're bringing out SONGS OF DONEGAL on Armistice Anniversary. The League of Nations will certainly look kindly on it. [...] I am sorry that I haven't a second copy of 
FEAR in my possession. The one you got was my last. Shall write a descriptive paragraph for your Spring List over week-end and you shall have same on Sunday morning.

Yours sincerely,

P.S.: By the way I would like to autograph three review copies of SONGS OF DONEGAL which you can send out in the usual way: one for Miss Norah Heald, who will do a review for Weekly Dispatch, one for the proprieter in whole part of several papers of South England, the Liverpool Courier (or Pest), the Notthinghan Guardian (?) and others. [...] Also one to Dr Crone of Irish Book Lover. The Derry Journal would be worth bearing in mind, for it's the paper read by all the priests in Donegal, Tyrone and Derry. These clergy hate me so much that they buy my books for the pleasure of burning them. Will call to autograph on Monday.

P.M.

En 1921, MacGill publica Fear, su última novela sobre la guerra que no es autobiográfica, pero sí contiene un número importante de personajes irlandeses, como McMahon, que comparten algunas características con el propio MacGill, "the face of poet and tussling with matters of religious beliefs" (Fear, 160-3). Según Philips (34), MacGill da total libertad a este personaje para mostrar un sentimiento anti-inglés, que MacGill no expresa en escritos anteriores. En realidad, MacGill en Fear hace su propia definición inclusiva de Englishness: "It's always our brave boys, our brave English boys, and it doesn't matter a damn whether their skins are black, white or piebald, whether they wear kilts or loin-cloths, they're still English" (56).

En 1923 publica Lanty Hanlon y Moleskin Joe - siendo este último uno de los memorables personajes que aparece en The Rat-Pit y Children of the Dead End - que era bien conocido por muchos de los irlandeses que trabajaban en Gran Bretaña en el siglo XX y cuya filosofía de vida era "there's a good time comin', although we may never live to see it". La mayoría de los artículos escritos sobre MacGill pasan por alto un detalle que puede resultar interesante: Moleskin Joe, antes de aparecer como novela, fue una obra de teatro, representada en el Ambassador's Theatre de Londres, según Wearing (77), en una sesión matinal el 7 de febrero de 1921 (dos años antes de la publicación de la novela). El 8 de febrero de 1921, un día después del estreno de la obra, el crítico del periódico The Scotsman escribe:

[...] The play introduced yesterday was by Mr Patrick MacGill and its title is "Moleskin Joe". The scene is laid in the Highlands, and the action oscillates between Dunrobin Farm and a neighbouring navvie's shack. [...] The faults of the play are palpable; there is not sufficient action, and what action there is is not sustained; the acts are arbitrarily conceived, and do not follow from one another, but are simply disconnected tableaux vivants, and the dialogue, amusing as it is, has a habit of not helping forward the action. [...] The author seems to have concentrated all his powers upon the portrayal of the navvy, and the result is that he has created one striking figure, but that he has left his other characters as mere amiable ciphers. Moleskin Joe is so good, however, that it is worth while, we should say, to give him a better chance, and no doubt Mr MacGill can do it.

No sabemos si MacGill leyó esta crítica o no, pero lo que sí es cierto es que el autor le dio otra oportunidad al personaje de Moleskin, convirtiéndolo en protagonista absoluto de su novela.

En septiembre de 1923 nacen sus gemelas Patricia y Christine. Un año más tarde, The Carpenter of Orra aparece en el mercado editorial. En esta novela, MacGill presenta la llegada de Cristo a una ciudad irlandesa en el siglo XX para transmitir su mensaje de amor y servicio a los demás. Resulta paradójico que MacGill presente la llegada de una figura de Cristo en una Irlanda supuestamente católica (Dudley Edwards 79), aunque quizás haya que ir un poco más allá y considerar esta novela como un intento de MacGill de "purgar los pecados cometidos" por sus 
ataques a determinados tipos de cura en novelas anteriores y reconciliarse con el estamento eclesiástico que vio con buenos ojos esta novela:

[...] "What", I asked, "is the attitude of the Roman Catholic Church to a book like "The Carpenter of Orra"?"

"Well, I am not now what one might call "a good Roman Catholic" [...] They looked upon 'The Carpenter of Orra' as a welcome return to orthodoxy on the part of one who in his extreme youth had kicked over the traces". [...] I left with an impression of an artist, singularly unacademic in mind and outlook, in close touch with the experiences of common men, who has a clear vision of the power and purpose of divine Love in human life. [...] (The Methodist Times, 17 February 1927)

En 1926, Sid Puddiefoot, el cuento de un hombre blanco que se forja un reino en África, ve la luz. Joe Sherrie (1971) cree que "the profesional novelist with the established reputation was at work, competent but unoriginal”. En 1928 nace su hija Sheila y publica The Black Bonar, que narra la historia de amor de Una Cassidy, abandonada por su padre a los 15 años y que vive con su madre viuda, y el hijo del terrateniente tirano, Kevin Bonar. En esta novela, MacGill se vuelve a repetir en el modelo de historia que ya usó en The Rat-Pit: chica pobre se enamora del hijo del terrateniente y crítica al "gombeen man".

A pesar de esta ausencia de nuevas ideas para sus novelas, el futuro de MacGill parecía asegurado por una reputación ganada a pulso y una compañera que estaba empezando a tener éxito, al menos en términos de ventas. Sin embargo, las malas noticias también llegaron a la familia MacGill: su hija Christine contrajo una tuberculosis glandular y, en 1927, cuando ésta tenía 5 años, la familia se trasladó a Leysin (Suiza) por recomendación médica, pasando 2 años antes de emprender rumbo a Estados Unidos en 1929.

MacGill y su familia se trasladan a Estados Unidos porque MacGill había llegado a un acuerdo para dar varias conferencias allí y porque veía la posibilidad de escribir guiones para la floreciente industria cinematográfica, pero en realidad no fue así y la única incursión en Hollywood fue la de su hija Sheila en la película Calvacade. La prensa se hace eco de este hecho:

Two years ago, Patrick MacGill, eminent Irish playwright and author, emigrated to Hollywood with his wife and three charming young daughters with the announced intention of "breaking into pictures". Neither MacGill nor his wife, also a popular author abroad, has succeeded in forcing open the Hollywood gates, but success has come to the MacGill family, nevertheless. Ironically enough, the one who has "made good in pictures" is Sheila, six-yearold daugther of the talented couple. (Glenn Innes Examiner, 1 April 1933)

En el momento de la llegada de los MacGill a Estados Unidos, la Gran Depresión estaba en marcha, las conferencias que tenía previstas fueron canceladas y MacGill y su familia sufrieron los rigores de la inmigración en California como cuenta su nieta Lucy Cuseo:

In 1929, my grandfather was offered a lecture tour of the United States and Canada. They happily agreed, loaded up the three girls and set sail for California. During the two or three weeks it took to sail from England to America the American stock market had crashed. Frivolous events like British authors going on tour took a back seat to trying to get the country off of its ear. My eight-year-old mother went from being a rich and pampered little girl to being a penniless immigrant just by stepping off the boat. They were stuck. My grandparents had been counting on the money from the lectures to finance their return passage. My mother said that they ate apricots -and only apricots- for an entire three month period. [...] My mother said that whenever a money transfer would arrive from the 
Mountbattens my grandmother would kiss the envelope and say, "Edwina has come up trumps!" My grandparents would then take the entire sum and blow it on something useless. They bought a car, for instance, when neither of them drove. (Open House, June/July 2013)

MacGill escribió una obra de teatro, Suspense (1930), estrenada en el Duke of York's Theatre el 8 de abril de ese mismo año de publicación, con Robert Douglas, Roland Culver and Gordon Harker como actores destacados. El crítico de The New Stateman compara Suspense con la exitosa obra de E.C. Sheriff, Journey's End (Greacen 13):

In both plays we watch a group of men desperately adjusting their wills and minds to cope with an abnormal situation which threatens to overwhelm them. I am bound to admit that the men in Suspense seemed to be good deal less real than those in the other dug-out. They have no background of suburban hollyhocks and playing-fields and all the warm, rich life of middle-class rural England to suggest their normal as distinct from their war personalities. MacGill's crowd of Tommies are men without pasts of futures, suffering entities flattened to a single aspect.

En agosto de ese mismo año, Suspense llegó a Broadway y el 3 de noviembre de 1930 se estrenó en el Reino Unido la película dirigida por Walter Summers. La revista Variety en su edición del 23 de julio de 1930 habla sobre el porqué del fracaso de la obra de teatro, compara el libreto de MacGill con el guión de la película y le augura poco éxito en Estados Unidos:

As a war play, Suspense flopped in London, although the critics generally rated it very high. The reason for its quick death was generally attributed to its outspokenness and that it was too strong for London taste. The talker version, as far as it goes, is a good piece of work. The problem is whether it represents entertainment in the ordinary sense. MacGill's original, even after licked by the censor, was pretty raw. In the talker it's been watered down to an occasional "ruddy", with a snatch of a naughty song. [...] Dialog has been stripped of the poetic values MacGill's original contained, and the whittling-down of the shell-shock sequences take away from the drama the atmosphere of futility and the antiwar propaganda with which it was filled. Suspense should do pretty well here with the better neighbourhood audiences, but it doesn't look like material for the States.

El autor de esta crítica, al calificar Suspense como "flopped in London" obvia que la obra de teatro se representó 62 veces en Londres desde el 8 de marzo de 1930 hasta el 31 de mayo de ese mismo año (Wearing 22), siendo un número de representaciones nada desdeñable para la escena londinense y para un autor no teatral, aunque sí tiene razón en el vaticinio de su fracaso en Estados Unidos: de la película no sabemos a ciencia cierta cuántas veces fue proyectada, pero la obra solamente se representó siete veces en agosto de 1930 en el Fulton Theatre de Nueva York.

Después de esta incursión teatral, MacGill continuó escribiendo novelas para Herbert Jenkins, entre ellas, Tulliver's Mill (1934), que narra la historia de Dorcote Mill, quien atraviesa problemas económicos que se resolverían con la venta del molino, pero su marido, Tulliver, se opone a desprenderse de un molino que ha pasado de generación en generación. La idea de MacGill es original porque está relacionada con los descendientes de los Tulliver, que aparecen en la novela The Mill on the Floss de George Eliot, pero, a diferencia de otras novelas, MacGill no es capaz de ahondar en la psicología de sus personajes y la novela pierde ese halo de genuidad que sí logró en sus novelas de temática de Donegal. En The Glen of Carra (1934), MacGill vuelve a ambientar su novela en Irlanda para narrar la historia de amor entre un joven inglés y la hija del dueño del castillo donde se aloja, Moira O’Donnell. En esta novela, la imaginación de MacGill se mezcla con duros momentos de realismo, pero esa aspereza que aparece en otras novelas suyas se ha 
evaporado. En 1935, MacGill publica The House at the World's End, cuya acción transcurre poco tiempo después de la Primera Guerra Mundial y donde MacGill describe la pobreza extrema de la familia Gallagher. En esta novela, recurre a la mitología irlandesa para presentar al lector un hada (en realidad, una vecina de los protagonistas) que se erigirá en salvadora de la familia al proporcionarles comida y adoptar a Hugie tras el fallecimiento de su madre. Según Sherrie (1971), “[...] Gone is MacGill's cynicism of his earlier years. The story is told with complete sympathy and compassion".

Helen Spenser (1937) fue la última novela publicada por Herbert Jenkins para MacGill y en una correspondencia de Herbert Jenkins Limited enviada a la dirección de MacGill - 1320-4 South Figueroa Street, Los Ángeles - para ser firmada, resulta llamativo el hecho que MacGill cede los derechos de Helen Spenser y The Diary of an Unwanted Girl a cambio de 150 libras y se compromete a revisar esta última novela: "I undertake to deliver to Herbert Jenkins, Ltd, by the 30th June 1936 a carefully revised and written version of THE DIARY OF AN UNWANTED GIRL, and I also agree to read the proofs of both books and make the necessary corrections" (O'Sullivan 212). Se desconoce el paradero del manuscrito de este libro y por qué no fue publicado por Jenkins, aunque Edwards (79) sugiere que el año de publicación de Helen Spenser coincide con la muerte del compañero de Jenkins, John Grimsdick, el 27 de diciembre de 1937 (Jenkins había fallecido el 8 de junio de 1923) y el hijo de Grimsdick, "lacked the memory of great days". Por su parte, O’Sullivan (212) cree que no fue publicada porque MacGill había vuelto a los temas y técnicas de The Rat-Pit.

Los últimos años de la vida de MacGill fueron años de pobreza y de deterioro de su estado de salud. Patrick contrajo esclerosis múltiple, que le hizo quedarse cojo y, a la larga, postrado en una cama. Continuó escribiendo hasta el final, aunque sus artículos no se vendían; una vez que las hijas eran mayores para trabajar y mantener a la familia, su mujer le hacía creer que todavía estaba recibiendo los derechos de autor. La mayor parte de la colección de libros de la familia tuvo que ser vendida. Su hija Christine dijo de aquella situación: "When times were hardest we would be sent to the second-hand bookstore to sell them, sometimes for as little as ten cents each. Then we'd go to the grocery store with the pennies and buy the necessities" (MacGill, Children of the Dead End IX).

Margaret Gibbons, la mujer de MacGill, intentó explotar su talento dramático abriendo una escuela de teatro, primero en Los Ángeles y luego en Miami, donde la familia se mudó en 1941, pero una vez Estados Unidos se unió a la guerra, los jóvenes desaparecieron y la escuela tuvo que cerrar. MacGill murió el 22 de noviembre de 1963 en el ostracismo más absoluto. Su muerte no apareció en los periódicos británicos como The Times o The Glasgow Herald - en parte porque había estado en silencio como autor durante muchos años y también porque las noticias sobre el asesinato de J.F. Kennedy el 22 de noviembre preocupaban más a los editores en aquel momento.

Patrick MacGill está enterrado junto a su esposa en el cementerio de St. Patrick en Fall River, Massachussets. Como epitafio, sus hijas escribieron uno de sus versos: "The old life fails, but the new life comes".

\section{Traducción de "The Cross", "I Will Go Back" y "The Trench"}

\section{The Cross}

(on the grave of an unknown British soldier, Givenchy, 1915)

The cross is twined with gossamer, The cross some hand has shaped with care. And by his grave the grasses stir But he is silent sleeping there.
The guns speak loud: he hears them not; The night goes by; he does not know; A lone white cross stands on the spot, And tells of one who sleeps below. The brooding night is hushed and still, The crooning breeze draws quiet breath. A star-shell flares upon the hill And lights the lowly house of death. Unknown, a soldier slumbers there, 
While mournful mists come dropping low. But oh! A weary maiden's prayer, And oh! A mother's tears of woe.

\section{La Cruz}

(en la tumba de un soldado británico desconocido, Givenchy, 1915)

La cruz está ceñida con una sutil telaraña, La cruz, alguna mano la ha labrado con esmero,

Y junto a su tumba las hierbas se agitan, Pero él en silencio duerme allí.

La artillería habla en voz alta: él no la oye,

\section{Will Go Back}

I'll go back again to my father's house and live on my father's land -

For my father's house is by Rosses' shore that slopes to Dooran strand,

And the wild mountains of Donegal rise upon either hand

I have been gone from Donegal for seven years and a day,

And true enough it's a long, long while for a wanderer to stay -

But the hills of home are aye in my heart and never are far away.

The long white road winds o'er the hill from

Fanad to Kilcar,

And winds apast Gweebara Bay where the deep sea-waters are -

Where the long grey boats go out by night to fish beyond the bar.

I'll lie by the beach the livelong day, where the foreshore dips to the sea.

When the sun is red on the golden gorse as once it used to be;

And, O! But it's many an olden thought will come up in the heart of me.

For the friends of my youth shall gather around, the friends that I knew of old,

The olden songs will be sung to me and the

old, old stories told

Beside the fire of my father's house when the nights are long and cold.

'Tis there that I'll pass my years away, back in my native land;

In my father's house by Rosses'shore that lies by Dooran strand,
La noche pasa: él no lo sabe.

Una solitaria cruz blanca aguanta allí mismo,

Y habla de uno que duerme abajo.

La iracunda noche está en silencio y todavía,

La brisa cantarina provoca una respiración

pausada

Una bengala fulgura en la montaña

E ilumina la humilde morada de la muerte.

Desconocido, un soldado duerme allí,

Mientras las tristes nieblas vienen goteando a

ras de tierra,

Pero ¡oh! El rezo de una sirvienta cansada

$\mathrm{Y} ¡ \mathrm{oh}$ ! Las lágrimas de aflicción de una madre.

Where the hills of ancient Donegal rise up on either hand.

\section{Regresaré}

Volveré otra vez a la casa de mi padre y

viviré de la tierra de mi padre -

Porque la casa de mi padre está junto a la costa de Rosses que se inclina hacia la playa de Dooran,

Y las salvajes montañas de Donegal se elevan a cada lado.

Llevo fuera de Donegal durante siete años y un día,

Y a decir verdad es un largo, largo período para que un errante resista -

Pero las colinas de casa sí están en mi corazón y nunca están lejos.

El largo camino blanco serpentea por la colina desde Faned to Kilcar,

Y serpentea por delante de la bahía de Gweebara donde las profundas aguas del mar están -

Donde los largos barcos grises salen por la noche a

pescar más allá de la barra.

Me tumbaré en la playa todo el santo día, donde la playa moja al mar -

Donde el sol es rojo sobre la dorada aulaga como solía ser antaño;

Y ¡oh! Pero más de un antiguo pensamiento aflorará en el corazón de uno.

Porque los amigos de mi juventud se reunirán, los amigos que conocí de mayor,

Me cantarán antiguas canciones y me contarán 
viejas, viejas historias

Junto al fuego de la casa de mi padre cuando las noches sean largas y frías.

"Es allí donde pasaré mis años, de vuelta a mi tierra natal;

\section{The Trench}

THE long trench, twisting, turning, wanders wayward as a river

Through the poppy-flowers blooming in the grasses dewy wet,

The buttercups sit shyly and the daisies nod and quiver,

Where the bright defiant bayonets rim the sandbagged parapet,

In the peaceful dawn the trenches hold a menace and a threat.

The last faint evening streamer touches heaven with its finger,

The vast night's starry legion sends its first lone herald star,

Around the bay and traverse little twilight colours linger

And incense-laden breezes come in crooning from afar,

To where above the sandbags gleam the steely fangs of war.

All the night the frogs go chuckle, all the day the birds are singing

In the pond beside the meadow, by the roadway poplar-lined,

In the field between the trenches are a million blossoms springing

'Twixt the grass of silver bayonets where the lines of battle wind

Where man has manned the trenches for the maiming of his kind.
En la casa de mi padre junto a la costa de Rosses que descansa junto a la playa Dooran, Donde las colinas del antiguo Donegal se elevan a cada lado.

\section{La Trinchera}

LA larga trinchera, que tuerce, que gira, vaga caprichosa como un río

A través de las amapolas que florecen en las hierbas mojadas por el rocío,

Los ranúnculos se sientan tímidamente y las margaritas se inclinan y tiemblan,

Donde las lustrosas y desafiantes bayonetas bordean el parapeto de sacos de arena,

En el tranquilo amanecer las trincheras guardan un aviso y una amenaza.

El último y débil serpentín de la tarde toca el cielo con su dedo,

La legión estrellada de la vasta noche envía su primera y solitaria estrella heraldo,

Alrededor de la bahía y el través los colores del pequeño crepúsculo tardan en marcharse

$\mathrm{Y}$ las brisas cargadas de incienso entran canturreando desde lejos,

Adonde sobre los sacos de tierra brillan los acerados colmillos de la guerra.

Durante toda la noche las ranas se echan a reír, todo el día los pájaros cantan.

En la charca junto a la pradera, por el camino de chopos alineados

En el campo entre las trincheras un millón de flores están floreciendo

Entre la hierba de bayonetas plateadas donde las líneas de batalla serpentean

Donde los hombres guarnecen las trincheras para la mutilación de su especie.

\section{Notas}

${ }^{1}$ Se incluye al final de este artículo la traducción al español por primera vez de tres de sus poemas más representativos: "The Cross", "I Will Go Back" y "The Trench", con permiso para su reproducción por parte de la agencia literaria Knight Features, Trident Business Centre, 89 Bickersteth Road, London SW17 9SH. 


\section{Obras citadas}

"A Talk with Patrick MacGill. Irish Poet on The Need for Brotherhood". The Methodist Times. 17 February 1927.

"Calvacade: The Picture of A Generation". The Glen Innes Examiner. 1 April 1933, 4.

Cuseo, Lucy. "Family Memories". Open House 230 (2013): 7.

Dudley Edwards, Owen. "Patrick MacGill and the Making of a Historical Source: with a Handlist of His Works." The Innes Review 37. 2 (1986): 73-100.

Greacen, Robert. Patrick MacGill: Champion of The Underdog. Glenties: Glenties Development Association, 1981.

"London Theatrical: A Play by Patrick MacGill". The Scotsman. 8 February 1921, 5.

MacGill, Patrick. Black Bonar. London: Herbert Jenkins, 1928. . Children of the Dead End. 1914. London: Caliban Books, 1985. . Fear. London: Herbert Jenkins, 1921. . Gleanings from a Navvy's Scrapbook. Greenock: P. MacGill, 1910. . Glenmornan. London: Herbert Jenkins, 1918. . Helen Spenser. London: Herbert Jenkins, 1937. Lanty Hanlon: a Comedy of Irish life. 1922. Dingle: Brandon, 1983. . Maureen. London: Herbert Jenkins, 1919. Moleskin Joe. 1923. Edinburgh: Birlinn, 2000. Sid Puddiefoot. London: Herbert Jenkins, 1926. Soldier Songs. 1916. London: Caliban Books, 1984. . Songs of a Navvy. Windsor: P. MacGill, 1912. . Songs of Donegal. 1921. London: Caliban Books, 1984. . Songs of the Dead End. 1913. London: Caliban Books, 1984. . Suspense. A Play in Three Acts. London: Herbert Jenkins, 1930. The Amateur Army. London: Herbert Jenkins, 1915. The Brown Brethren. New York: George H. Doran, 1917. The Carpenter of Orra. London: Herbert Jenkins, 1924. The Diggers: The Australians in France. London: Herbert Jenkins, 1919. The Dough-Boys. New York: George H. Doran, 1919. The Glen of Carra. London: Herbert Jenkins, 1934. The Great Push. 1916. Edinburgh: Birlinn, 2000. The Rat-Pit. 1915. Edinburgh: Birlinn, 1999. The Red Horizon. Dingle: Brandon, 1984. The House at the World's End. London: Herbert Jenkins, 1935. . Tulliver's Mill. London: Herbert Jenkins, 1934.

Letter to Canon Dalton. 24 November 1911. Oxford University: Worcester College Library.

. Letter to Canon Dalton. 18 January 1912. Oxford University: Worcester College Library. . Letter to Herbert Jenkins. 27 February 1919. Berg Collection, New York Public Library . Letter to Canon Dalton. 30 April 1919. Oxford University: Worcester College Library. Letter to Herbert Jenkins. 5 November 1920. Berg Collection, New York Public Library

"MacGill, Patrick. The Navvy Poet at Windsor: Interview with Mr. Patrick MacGill". Daily Express. 19 February 1913.

O'Sullivan, Patrick. "Patrick MacGill: The Making of A Writer". Ireland Histories: Aspects of State, Society and Ideology. Ed. S. Hutton and P. Stewart. London and New York: Routledge, 1991. 203-222. 
Phillips, Terry. "The Wisdom of Experience: Patrick MacGill's Irishness Reassessed". SubVersions, Transnational Readings of Modern Irish Literature. Ed. Ciaran Ross. Amsterdam and New York: Rodopi, 2010. 29-52.

Pulido Palomo, José Manuel. "Patrick MacGill: estudio comparativo de Children of the Dead End, The Rat-Pit, Glenmornan y Moleskin Joe". Tesis doctoral. Universidad Complutense de Madrid, 2009. Eprints.ucm. Web.18 Dic 2009.

Sherrie, Joe. "The Voice of the Inarticulate". Irish Press. 28 July 1971.

Starr, Robert. Nailed to The Rolls of Honour, Crucified: Irish Literary Responses to the Great War: The War Writings of Patrick MacGill, James Hanley, and Liam O'Flaherty. Diss. University of Warwick, 2017. Stuttgart, Germany: ibidem-Verlag, Jessica Haunschild u Christian Schon, 2019.

"Still MacGill". The Sunday Times. 20 January 1918, 13.

Wearing, John Peter. A Calendar of Productions, Performers, and Personnel. 2nd ed. Lanham, MD, United States: Rowman and Littlefield Publishers, 2014.

. The London Stage: 1930-1939. A Calendar of Productions Performer and Personnel. Lanham, MD, United States: Rowman and Littlefield Publishers, 2014.

"Suspense". Variety. 23 July 1930, 31.

José Manuel Pulido Palomo es Doctor en Filología Inglesa por la UCM con la tesis titulada "Patrick McGill: estudio comparativo de Children of The Dead End, The Rat-Pit, Glenmornan y Moleskin Joe", bajo la dirección de la Doctora Beatriz Villacañas, y Licenciado en Filología Inglesa por la Universidad de Extremadura. Ha sido profesor de los Cursos de Verano del Centro Superior de Idiomas Modernos de la UCM, Profesor del Máster de Formación de Profesorado en la Universidad Antonio de Nebrija, preparador de exámenes de la OTAN en la Escuela Militar de Idiomas de Madrid y formador de cursos de inglés para personal sanitario y hostelero. Actualmente imparte docencia a alumnos de Secundaria y Bachillerato en el Colegio San Buenaventura de Madrid y coordina las inmersiones e intercambios con Irlanda.

josepulidopalomo@gmail.com 